\title{
Utjecaj kišnih glista Lubricus rubellus na brojnost mikroorganizama u zemljištu tretiranom pendimetalinom
}

\section{Sažetak}

U radu je ispitivano na koji način kišna glista Lumbricus rubellus svojom aktivnošću utječe na brojnost različitih fizioloških grupa mikroorganizama u zemljištu tretiranim pesticidom Stomp 330 E čija je aktivna supstanca pendimetalin. Eksperiment je postavljen u 10 staklenih kontejnera sa zemljišnim supstratom, pri čemu je jedan kontejner bio kontrolni, a po tri kontejnera su tretirana s tri različite koncentracije pendimentalina. Korištena je deklaracijom preporučena koncentracija pesticida od $5 \mu \mathrm{l} / \mathrm{kg}$, jedna niža koncentracija od $3 \mu \mathrm{l} / \mathrm{kg}$ i jedna viša koncentracija od $7 \mu \mathrm{l} / \mathrm{kg}$. Brojnost fizioloških grupa mikroorganizama je određena iz tri komore tretirane različitim koncentracijama pendimetalina 48 sati nakon tretmana, a iz druge tri komore 21 dan nakon tretmana. Kako bi se utvrdilo postoji li interakcija između aktivnosti kišnih glista i brojnosti mikroorganizama u zemljištu kontaminiranom pesticidom u tri komore je pored navedenih koncentracija pesticida ubačeno po 10 odraslih jedinki vrste Lumbricus rubellus. Mikrobiološka analiza supstrata je izvršena 21 dan nakon tretmana. Utvrđeno je da je dva dana nakon primjene različitih koncentracija pesticida došlo do statistički značajnog opadanja brojnosti gljivica i celulolitičkih mikroorganizama u zemljištu, dok se brojnost ukupnih heterotrofnih bakterija, kao i mikroorganizama koji sudjeluju u različitim etapama metabolizma dušika višestruko povećala. Međutim, 21 dan nakon provođenja tretmana zabilježen je značajan pad brojnosti ukupnih heterotrofnih bakterija u svim tretiranim kontejnerima u odnosu na kontrolni, pri čemu su kišne gliste svojom aktivnošću djelomično ublažile negativan efekt pendimentalina na ukupnu zemljišnu bakteriofloru te su pozitivno djelovale na brojnost gljivica, aktinomiceta i celulolitičkih mikroorganizama, dok na brojnost aminoautotrofa, oligonitrofila i slobodnih dušičnih fiksatora prisustvo kišnih glista u zemljištu nije imalo značajan utjecaj. Pokazalo se da kišne gliste svojom aktivnošću ublažavaju negativno djelovanje pesticida Stomp 330 E na bakteriofloru i gljivice, čime se ističe njihova moguća upotreba u procesima bioremedijacije.

Ključne riječi: kišne gliste, Lumbricus rubellus, pendimentalin, broj mikroorganizama u zemljištu

\section{Uvod}

Zemljište predstavlja jedan od najvažnijih resursa, ne samo u poljoprivrednoj proizvodnji već i u pogledu održavanja ekosustava u cjelini. Ono se u dugotrajnom procesu pedogeneze sporo obrazuje, ali se neadekvatnim korištenjem često vrlo brzo uništava i oštećuje (Kljajić i sur., 2012). Kvaliteta zemljišta u znatnoj mjeri ovisi o aktivnosti mikroorganizama čiji enzimi imaju centralnu ulogu u zemljišnom metabolizmu. Njihova brojnost se kreće od nekoliko milijuna do nekoliko milijardi po gramu apsolutno suhog zemljišta (Milošević, 2008). Izuzetno su značajni za pedogenezu, stvaranje i održavanje plodnosti zemljišta. Ukupan broj mikroorganizama u zemljištu se može koristiti kao pokazatelj njegove opće biološke aktivnosti (Milošević i sur., 2001; Imberger i Chiu, 2002; Radivojević i sur., 2003).

\footnotetext{
Doc. dr. sc. Igor Milunović, doc. dr. sc. Svjetlana Lolić, doc. dr.sc. Biljana Lubarda, Prirodno-matematički fakultet, Banja Luka,

Dr. Mladena Stojanovića 2,78000 Banja Luka, Bosna i Hercegovina

Prof. dr. sc. Vojislav Trkulja, JU Poljoprivredni institut Republike Srpske,

Knjaza Miloša 17, 78000 Banja Luka, Bosna i Hercegovina

Autor za korespondenciju: i.milunovic@inspektorat.vladars.net
} 
U intenzivnoj poljoprivrednoj proizvodnji se u znatnoj mjeri koriste pesticidi koji dospijevaju u zemljište gdje na različite načine utječu na autohtonu zemljišnu mikrofloru. Na većinu populacija mikroorganizama pesticidi djeluju tako da im mijenjaju brojnost, aktivnost i brzinu razmnožavanja (Johansen i sur., 2001). Neke fiziološke grupe mikroorganizama imaju sposobnost razgradnje pojedinih vrsta pesticida i koriste ih kao izvor biogenih elemenata što dovodi do rasta mikrobne populacije (Janjić, 1996). Neki mikrobi, naročito bakterije, mogu koristiti pesticide kao izvor hranjivih materija koji olakšavaju njihov rast i opstanak, dok osjetljive vrste mogu biti oštećene ili uništene pesticidima. Ove ekološke izmjene mogu izazvati kaskadu indirektnih efekata. Na primjer, eliminacija ili smanjenje određenih mikrobioloških populacija pesticidima može osloboditi mikrobe tolerantne na pesticide od borbe za zajedničke resurse i na taj način potaknuti njihov rast i opstanak. Slično tome, neke protozoe napadaju bakterije i njihovo suzbijanje pesticidima može olakšati opstanak tih bakterija. Ovi procesi mogu dovesti do dramatičnih promjena u mikrobiološkim zajednicama koje mogu ometati ili imati blagi utjecaj na mikrobiološke funkcije. S druge strane, djelovanje pesticida na mikroorganizme može biti smrtonosno i može dovesti do promjene biodiverziteta postojeće mikrobiološke zajednice u zemljištu (Muturi i sur., 2017., Jacobsen i Hjelmsø, 2014).

Utjecaj pesticida na mikrobiološku zemljišnu zajednicu zavisi od njihove toksičnosti, koja određuje rizik i njihovu sudbinu u zemljištu, čijim postojanjem upravlja nekoliko procesa, kao što su adsorpcija, isticanje, odljev, degradacija, isparavanje, uzimanje nutrienata od strane biljaka itd. (Pose-Juan i sur., 2017) i na taj način njihove aktivnosti utječu na mikrobiološku ekološku ravnotežu u zemljištu, kao i na produktivnost zemljišta (Kaur i sur., 2014).

Na brojnost mikroorganizama u zemljištu utječe i aktivnost zemljišnih beskralježnjaka, a naročito kišnih glista, budući da tijekom probavljanja usitnjavaju i izbacuju organske materije, čime se stvara veće površinsko područje za djelovanje mikroorganizama (Edwards i Bohlen, 1996).

Cilj istraživanja bio je, u laboratorijski kontroliranim uvjetima, utvrditi djelovanje pendimentalina na brojnost pojedinih fizioloških grupa mikroorganizama u zemljištu, kao i da se utvrdi na koji način kišna glista Lumbricus rubellus (Hoffmeister, 1843) utječe na populacije mikroorganizama u tretiranom zemljištu.

\section{Materijal i metode}

Pendimetalin je aktivna materija pesticida Stomp 330 E. To je selektivni herbicid iz grupe dinitroanilina namijenjen za preemergentnu kontrolu jednogodišnjih travnih i širokolisnih korova (Tomlin, 2000). Primarno se koristi u raznim poljoprivrednim usjevima - $92 \%$ od ukupne upotrebe (Janjić, 1996., Chikoye i sur., 2014), ali i na urbanim područjima: primjenjuje se na travnjacima okućnica, popločanim područjima, stazama, dvorištima, u industrijskim zonama i na golf terenima (WSDA, 2004). Djelovanje ostvaruje na taj način što zaustavlja diobu stanica što ima za posljedicu zaustavljanje rasta korova u fazi nicanja i klijanja.

Pendimetalin $\left(\mathrm{C}_{13} \mathrm{H}_{19} \mathrm{~N}_{3} \mathrm{O}_{4}\right)$ (Slika 1$)$ je slabo ispariv i slabo mobilan herbicid. Na njegovu perzistentnost utječu kako način kultivacije, tako i uvjeti vlažnosti, temperatura i tip zemljišta (Savage, 1980; Schleicher i sur., 1995). Najperzistentniji je u glinenom zemljištu i duže je aktivan ukoliko je inkorporiran, nego primijenjen na površini zemljišta odakle postupno isparava (Savage, 1980; Zimdahl, 1984). Relativno je stabilan i nepokretan u supstratu, ali se polako degradira pod vodenom fotolizom, s periodom razlaganja od 21 dan, dok je aerobni zemljišni metabolizam oko 172 dana. Pendimetalin nije otrovan za pčele, ptice i sisare, ali je visoko toksičan za ribe i vodene beskralježnjake (Zulalian, 1990) pa ga ne treba primjenjivati u blizini potoka i jezera. 


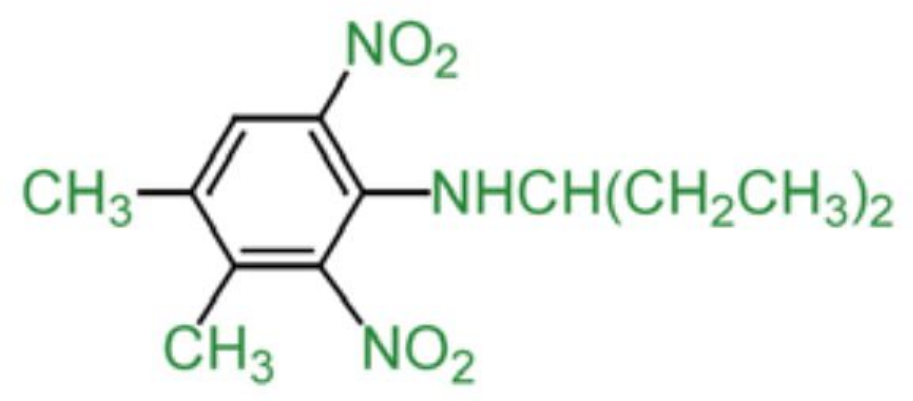

Slika 1. Strukturna formula pendimetalina (Tomlin, 2000).

Eksperiment je postavljen u staklenim kontejnerima dimenzija 20×20×10 cm koji su staklenom pregradom podijeljeni na dvije jednake komore. Svaka komora je napunjena sa $1.500 \mathrm{~g}$ zemljišnog supstrata pripremljenog po standardu ISO 17512-1. Supstrat se sastojao od $70 \%$ kaoliniske gline (glina s $30 \%$ kaolina), $20 \%$ kvarcnog pijeska sitne granulacije i $10 \%$ treseta. Kako bi se utvrdio utjecaj pendimetalina na populacije mikroorganizama u zemljištu komore su tretirane pesticidom Stomp 330E (proizvođač "BASF", Njemačka) i to s njegove tri različite koncentracije. Korištena je deklaracijom preporučena koncentracija pesticida od $5 \mu \mathrm{l} / \mathrm{kg}$, jedna niža koncentracija od $3 \mu \mathrm{l} / \mathrm{kg}$ i jedna viša koncentracija od $7 \mu \mathrm{l} / \mathrm{kg}$. Brojnost pojedinih grupa mikroorganizama je određena iz tri komore tretirane različitim koncentracijama pendimetalina 48 sati nakon tretmana, a iz druge tri komore 21 dan nakon tretmana. Kako bi se utvrdilo da li postoji interakcija između aktivnosti kišnih glista i brojnosti mikroorganizama u zemljištu kontaminiranom pesticidom u tri komore je pored navedenih koncentracija pesticida ubačeno po 10 odraslih jedinki vrste Lumbricus rubellus i analiza supstrata je izvršena 21 dan nakon tretmana. Kao kontrola je korištena komora koja je sadržavala samo zemljišni supstrat, bez dodavanja herbicida i bez prisustva kišnih glista. U svim komorama je elektro-mješalicima izvršena ravnomjerna disperzija herbicida i ujednačavanje vlažnosti supstrata na $60 \%$ u odnosu na retencijski vodni kapacitet. Eksperiment je postavljen u laboratoriju Prirodno-matematičkog fakulteta u Banjaluci, a mikrobiološka ispitivanja su vršena u laboratoriju za mikrobiologiju na Institutu za zemljište u Beogradu.

Sterilnim priborom je sakupljen prosječan uzorak po tretmanu, težine oko $300 \mathrm{~g}$, koji je formiran od uzoraka uzetih s 5 točaka: jedna iz sredine komore i 4 sa sredina dijagonala, s tim da je jedna točka obuhvaćala cijelu dubinu komore. Za određivanje brojnosti odabranih fizioloških grupa mikroorganizama korištena je indirektna uzgajivačka metoda pri čemu su sva zasijavanja vršena u tri ponavljanja. Određen je ukupan broj heterotrofnih mikroorganizama, brojnost gljivica, aktinomiceta, celulolizatora, aminoautotrofa, aminoheterotrofa, oligonitrofila i slobodnih dušičnofiksirajućih bakterija (Sarić, 1992).

Ukupan broj heterotrofnih bakterija je određen metodom agarnih ploča sa zemljišnim ekstraktom. Zasijano je po $1 \mathrm{ml}$ razrjeđenja $10-6$ i nakon 7 dana inkubacije na $28^{\circ} \mathrm{C}$ su izbrojane sve izrasle kolonije. Brojnost gljivica u zemljištu je određena indirektnom metodom agarnih ploča na Czapek agaru. Zasijano je po $1 \mathrm{ml}$ razrjeđenja $10-4$ i nakon 3 dana inkubacije na $28^{\circ} \mathrm{C}$ su izbrojane sve izrasle kolonije gljivica. Aktinomicete su određene metodom agarnih ploča na podlozi sa saharozom po Krasiljnikovu (1965). Zasijano je po $1 \mathrm{ml}$ razrjeđenja 10-4 i nakon 7 dana inkubacije na $28^{\circ} \mathrm{C}$ su izbrojane sve izrasle kolonije.

Broj celulolizatora je određena na Waksman-Carey podlozi na koju je stavljen sterilan filter papir kao izvor ugljika. Zasijana je cijela površina filter papira s 0,5 ml uzorka razrjeđenja 10-4. Zasijana podloga je inkubirana 21 dan u termostatu na temperaturi od $28^{\circ} \mathrm{C}$. Brojnost aminoa- 
utotrofnih bakterija je određena na škrobno-amonijačnom agaru pri čemu je zasijano po $1 \mathrm{ml}$ razrjeđenja $10-5$ i nakon 7 dana inkubacije na $28^{\circ} \mathrm{C}$ su izbrojane izrasle kolonije. Brojnost oligonitrofila je određena na Eshbi-jevoj podlozi s manitom tako što je zasijano po $1 \mathrm{ml}$ razrjeđenja 10-5 i kolonije su izbrojane nakon 7 dana inkubacije na $28^{\circ} \mathrm{C}$. Brojnost slobodnih dušičnih fiksatora je određena na Fjodor-ovoj podlozi (Govedarica i Jarak, 1996). Zasijano je po 0,5 ml razrjeđenja $10-5$ i nakon 5 dana inkubacije u termostatu na $28^{\circ} \mathrm{C}$ su izbrojane izrasle kolonije.

\section{Rezultati i rasprava}

Primjena pendimetalina je u znatnoj mjeri utjecala na brojnost ukupnih heterotrofnih bakterija u zemljištu (Grafikon 1). U odnosu na kontrolni eksperiment gdje zemljište nije tretirano herbicidom niti je sadržavalo jedinke kišnih glista, 48 sati od primjene niže i više koncentracije pendimetalina od deklaracijom preporučene koncentracije došlo je do značajnog povećanja brojnosti ukupnih heterotrofnih mikroorganizama u zemljištu. Međutim, 21 dan nakon primjene herbicida ukupna brojnost mikroflore u svim kontejnerima je višestruko opala, bez obzira na njegovu primijenjenu koncentraciju. Pritom je u kontejnerima koji su sadržavali kišne gliste brojnost ukupnih heterotrofa bila statistički značajno veća u odnosu na kontejnere bez glista. Domsch i Grams (1983) su pokazali da mikroorganizmi na početku imaju „korist" od transformacije herbicida jer se razlaganjem kompleksnih molekula oslobađa dušik i ugljik. Međutim, nakon početnog rasta, mnogi autori su zabilježili pad brojnosti mikroorganizama nakon primjene različitih vrsta pesticida (Očinikova, 1976; Očinikova i Orlov, 1980; Đorđević i sur., 1994; Govedarica i sur., 1996; Tamburić i Lević, 1995; Radivojević, 1998). Ipak dvostruko veća brojnost ukupne mikroflore, od koje u znatnoj mjeri ovisi sama kvaliteta zemljišta, u zemljištu koje je sadržavalo kišne gliste u odnosu na zemljište bez ovih organizama, pokazuje da kišne gliste svojom aktivnošću donekle ublažavaju negativno djelovanje pesticida na mikrobnu floru.

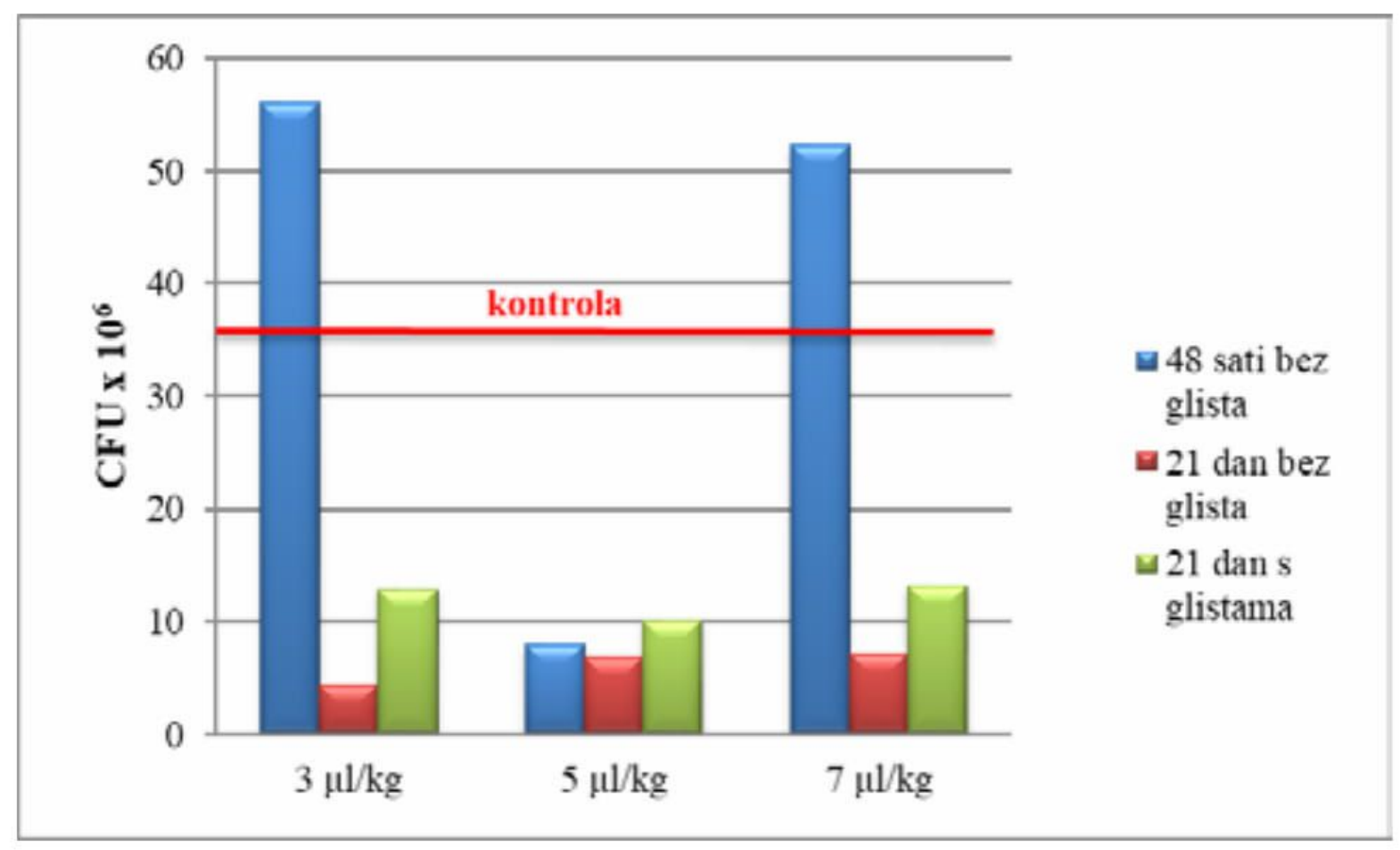

Grafikon 1. Brojnost ukupnih heterotrofnih bakterija u zemljištu ovisno o koncentraciji pendimentalina i prisustvu vrste Lumbricus rubellus 
Brojnost gljivica u zemljištu 48 sati nakon tretmana pesticidom sa sve tri primijenjene koncentracije značajno je opala u odnosu na broj gljivica u kontrolnom kontejneru (Grafikon 2). Najveći pad njihove brojnosti zabilježen je prilikom korištenja najveće koncentracije pesticida. U zemljištu koje nije sadržalo kišne gliste brojnost ove grupe organizama nije se bitno promijenila ni 21 dan nakon provođenja tretmana. Međutim, u kontejnerima u kojima su se nalazile kišne gliste 21 dan nakon tretiranja pesticidom došlo je do značajnog povećavanja brojnosti gljivica u zemljištu. $U$ kontejneru u kom je primijenjena koncentracija pendimentalina od 3 $\mu \mathrm{l} / \mathrm{kg}$ brojnost gljivica se utrostručila, tj. povećala se sa $26.700 \mathrm{CFU} / \mathrm{g}$ na $87.700 \mathrm{CFU} / \mathrm{g}$. S primjenom preporučene koncentracije pesticida njihova brojnost u zemljištu se udvostručila, a $\mathrm{s}$ primjenom veće koncentracije brojnost im se povećala za $58 \%$ u odnosu na brojnost gljivica $u$ kontrolnom kontejneru.

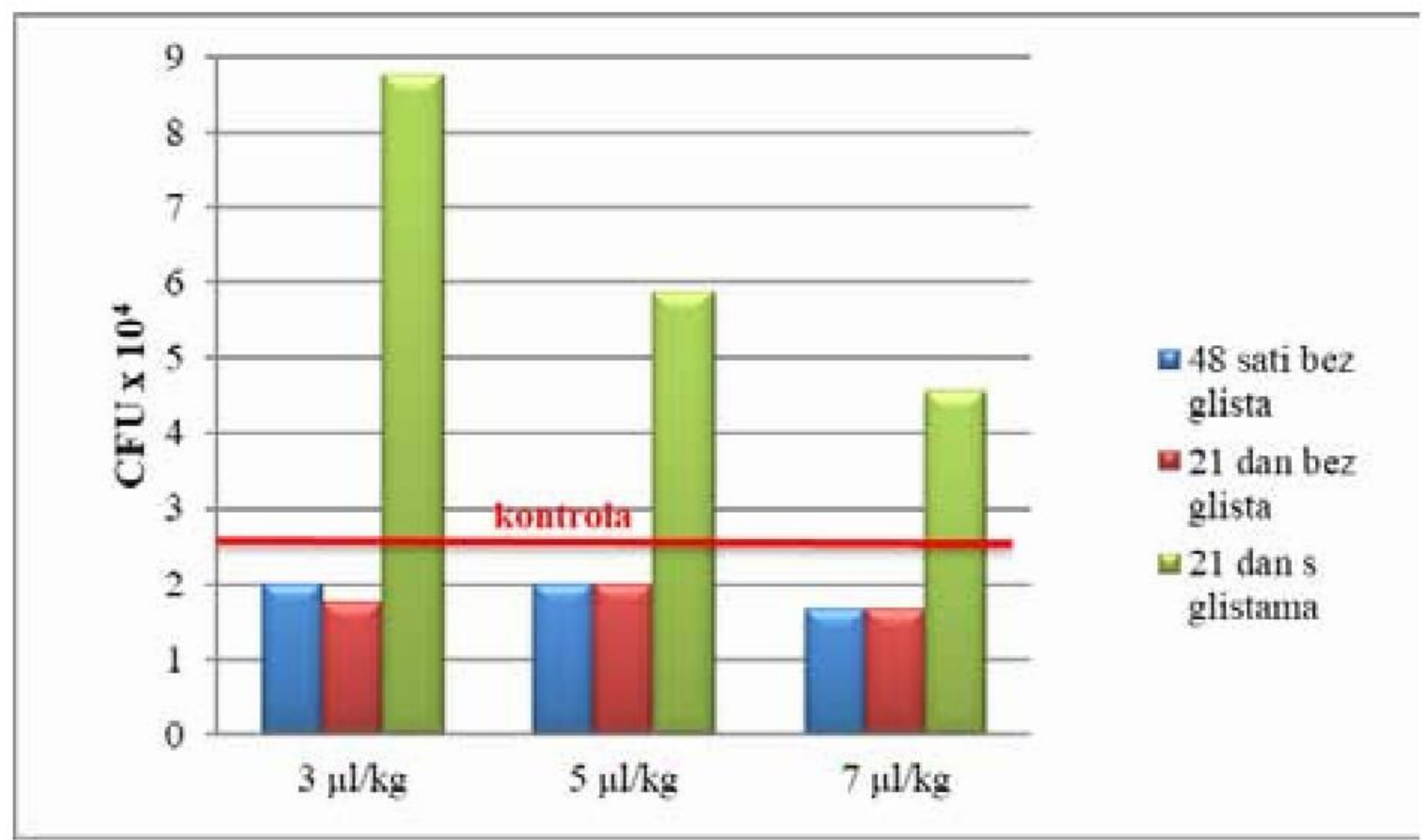

Grafikon 2. Brojnost gljivica u zemljištu ovisno o koncentraciji pendimentalina i prisustvu vrste Lumbricus rubellus.

Grossbard i Devies (1976) navode da su gljivice u odnosu na druge grupe mikroorganizama otpornije na djelovanje pesticida, prvenstveno zbog toga što imaju enzimske sisteme koji su sposobni razgrađivati molekule pesticida i tako ih koriste kao izvore biogenih elemenata i energije za svoje fiziološke procese. Također, slične rezultate navode i Radivojević i Stanković-Kalezić (2000) koje su utvrdile da poslije početnog inhibitornog djelovanja pendimetalina dolazi do obnavljanja populacije gljivica jer se uključuju u procese razgradnje molekula pendimetalina.

Brojnost aktinomiceta u zemljištu 48 nakon tretmana pendimentalinom se značajno smanjila samo prilikom upotrebe najveće koncentracije pesticida (Grafikon 3). 21 dan nakon njegove primjene zabilježeno je značajno smanjenje brojnosti ove grupe mikroorganizama u svim kontejnerima u kojima nisu bile prisutne kišne gliste, bez obzira na primijenjenu koncentraciju pesticida. Međutim, u kontejnerima u kojima su bile prisutne i kišne gliste, brojnost aktinomiceta je bila dvostruko smanjena samo u kontejneru u kom je primijenjena preporučena koncentracija pendimentalina od $5 \mu \mathrm{l} / \mathrm{kg}$, dok su primjena više i niže koncentracije pesticida 
dovele do značajnog povećavanja njihove brojnosti. Jarak i Govedarica (2003) ističu da ova grupa mikroorganizama ima sposobnost razlaganja i najotpornijih komponenti humusa, pektina, lignina, kao i pesticida i drugih ksenobiotika. Iz provedenog eksperimenta se vidi da njihova aktivnost ovisi o koncentraciji primijenjenog pesticida, ali i da kišne gliste svojom aktivnošću pozitivno djeluju na njihov metabolizam, što rezultira povećanjem njihove brojnosti u zemljištu, a samim tim i do poboljšanja kvalitete samog zemljišta.

Slični rezultati su dobili i Kočarek i sur. (2016), gdje je konstatirano da se broj mikroorganizama (bakterija, gljivica i spora) na kraju eksperimenta kretao u sličnom intervalu kao i na početku, a broj aktinomiceta značajno se povećao na kraju eksperimenta, iako nije bilo razlike u tretmanima na početku, kao ni na kraju eksperimenta.

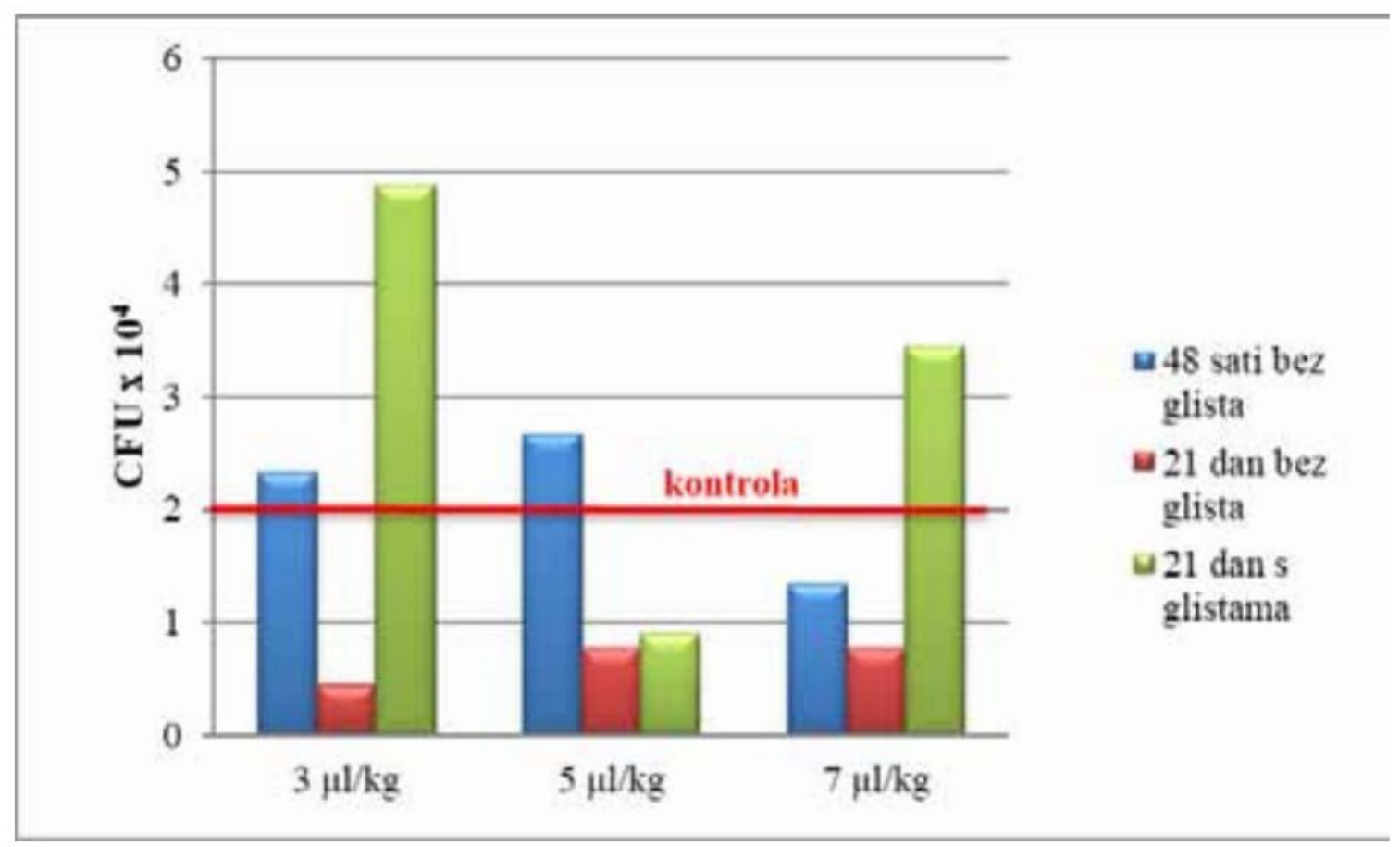

Grafikon 3. Brojnost aktinomiceta u zemljištu ovisno o koncentracijei pendimentalina i prisustvu vrste Lumbricus rubellus.

Upotreba pendimentalina u zemljištu je dovela do povećanja brojnosti mikroorganizama koji imaju sposobnost razgradnje celuloze (Grafikon 4) u odnosu na kontrolni uzorak. 48 sati nakon primjene najniže koncentracije pesticida došlo je do smanjenja njihove brojnosti, dok pri upotrebi viših koncentracija nije zabilježena statistički značajna razlika u odnosu na kontrolni uzorak $(p=0,05)$. Međutim, 21 dan nakon primjene tretmana došlo je do značajnog porasta njihove brojnosti, naročito u kontejnerima koji su sadržavali i kišne gliste, u kojima se brojnost celulolizatora udvostručila u odnosu na kontrolni kontejner. Prema tome, nakon početne faze prilagođavanja, pendimentalin je pozitivno djelovao na brojnost celulolizatora u zemljištu, čemu je još više doprinijela aktivnost kišnih glista. 


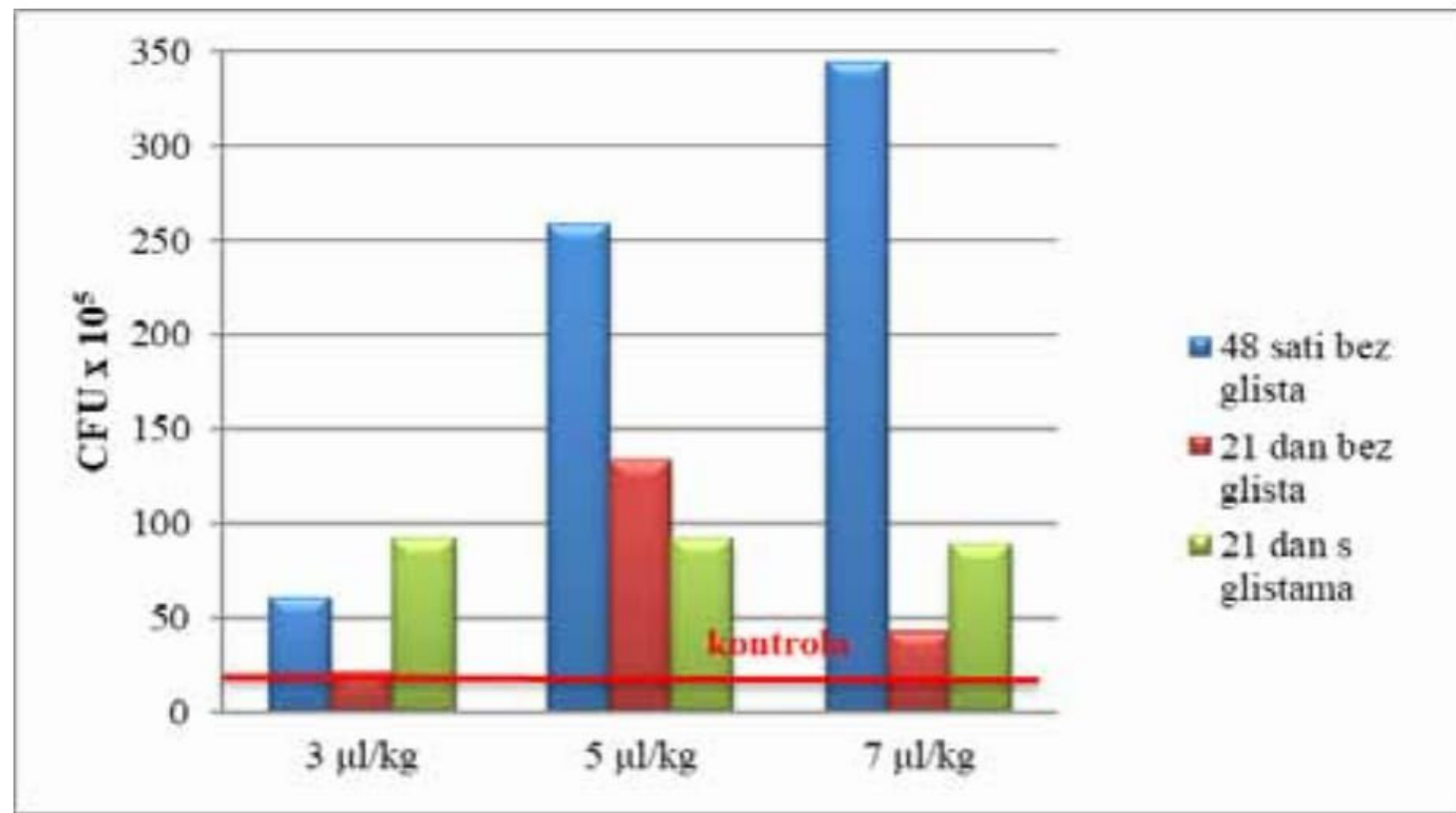

Grafikon 4. Brojnost celulolizatora u zemljištu ovisno o koncentraciji pendimentalina i prisustvu vrste Lumbricus rubellus.

Brojnost aminoautotrofa koji u ishrani koriste dušik iz neorganskih jedinjenja se statistički značajno povećala $(p=0,05)$ u odnosu na kontrolu u svim kontejnerima izuzev prilikom primjene najniže koncentracije pendimentalina 21 dan nakon tretmana (Grafikon 5). Do najvećeg rasta brojnosti došlo je odmah 48 sati nakon primjene pesticida, pri čemu je brojnost ove grupe bakterija bila veća što je bila viša koncentracija primijenjenog pesticida. Aminoautotrofi su koristili mineralni oblik dušika koji se oslobađa razgradnjom pendimentalina, što je dovelo do povećanja njihove brojnosti na samom početku eksperimenta. Nakon 21 dana s opadanjem koncentracije pesticida u zemljištu opala je i brojnost ove grupe mikroorganizama, neovisno o prisustvu kišnih glista u zemljištu.

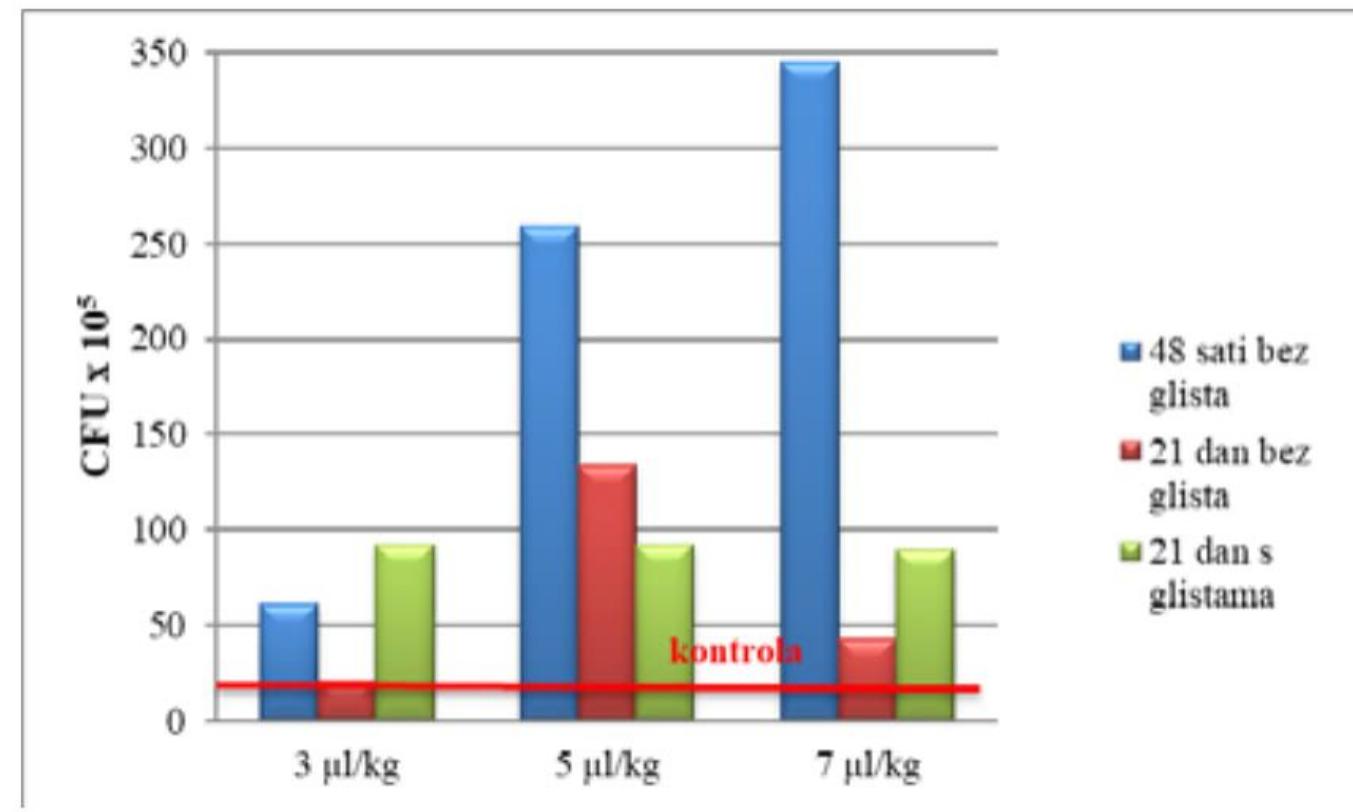

Grafikon 5. Brojnost aminoautotrofa u zemljištu ovisno o koncentraciji pendimentalina i prisustvu vrste Lumbricus rubellus. 
Brojnost oligonitrofila u zemljištu, koji opstaju u sredinama s niskim koncentracijama dušika zbog izražene sposobnosti iskorištavanja dušičnih spojeva, kretala se slično kao i brojnost aminoautotrofa. U odnosu na kontrolni kontejner brojnost oligonitrofila se nakon dodavanja pendimentalina povećala i više od $400 \%$ u svim testnim kontejnerima izuzev prilikom primjene najniže koncentracije 21 dan nakon tretmana (Grafikon 6). Kao i u slučaju aminoautotrofa, brojnost oligonitrofila se najviše povećala nakon samog tretmana, pri čemu se u kontejneru s najvećom koncentracijom pesticida njihova brojnost povećala čak 34 puta. Također, prisustvo kišnih glista nije imalo utjecaj na brojnost ovih mikroorganizama u zemljištu.

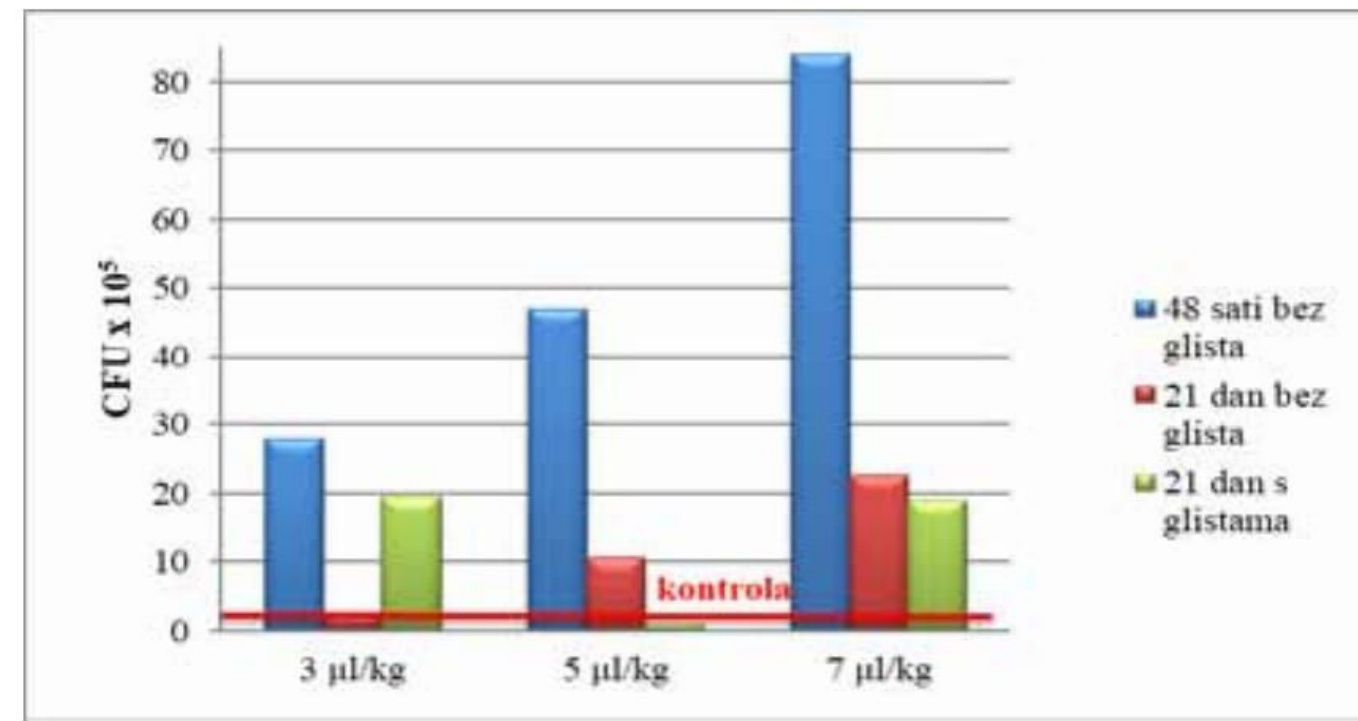

Grafikon 6. Brojnost oligonitrofila u zemljištu ovisno o koncentraciji pendimentalina i prisustvu vrste Lumbricus rubellus.

Potpuno ista situacija je bila i sa slobodnim dušičnim fiksatorima, tj. bakterijama koje imaju sposobnost asimbiontskog vezivanja elementarnog dušika i njegovog prevođenja u mineralne oblike. Njihova brojnost u zemljištu se višestruko povećala 48 sati nakon primjene pendimentalina, pri čemu je njihov broj bio veći što je bila viša koncentracija primijenjenog pesticida. 21 dan nakon tretmana njihova brojnost u zemljištu je u znatnoj mjeri opala, nevezano da li su u kontejnerima bile prisutne kišne gliste ili ne.

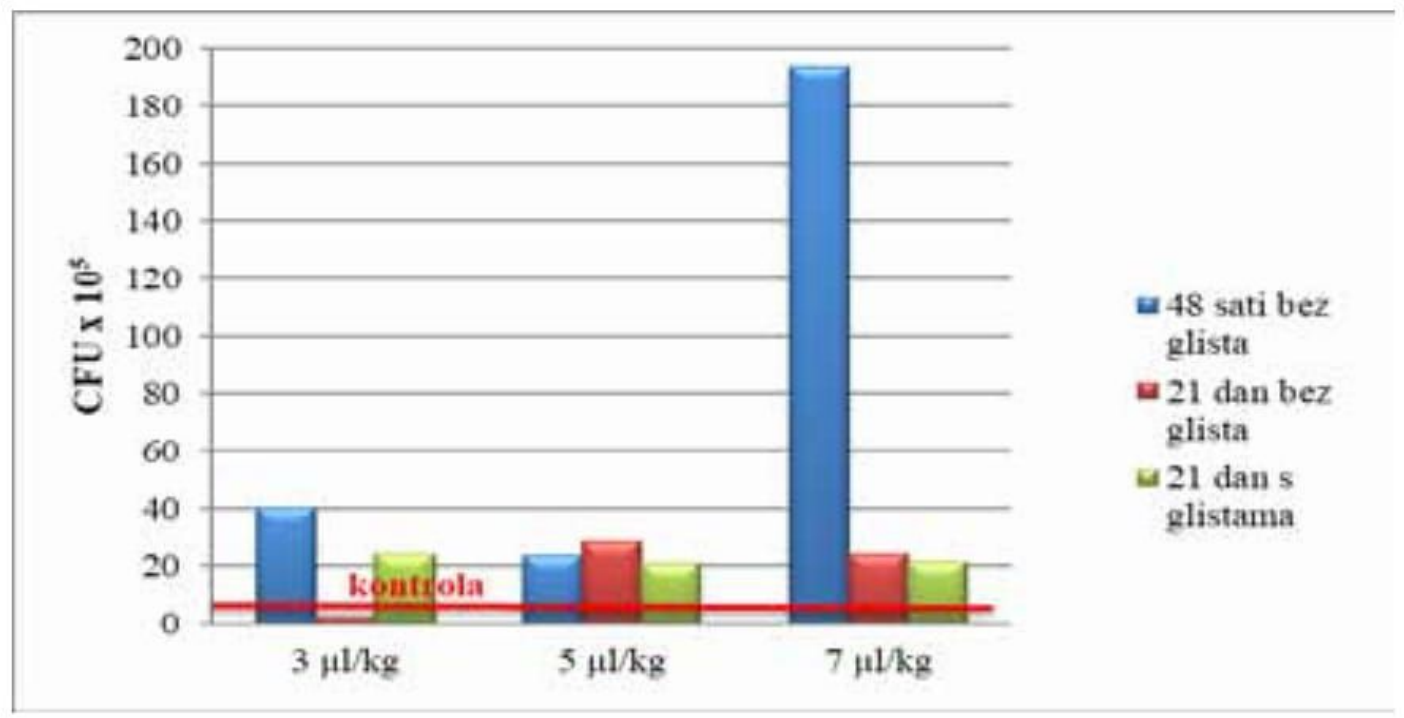

Grafikon 7. Brojnost slobodnih dušičnih fiksatora u zemljištu ovisno o koncentraciji pendimentalina i prisustvu vrste Lumbricus rubellus. 
Provedeni eksperiment pokazuje da primjena pendimentalina u znatnoj mjeri utječe na populaciju mikroorganizama u zemljištu. Dva dana nakon primjene različitih koncentracija pesticida došlo je do statistički značajnog opadanja brojnosti gljivica i celulolitičkih mikroorganizama u zemljištu, dok se brojnost ukupnih heterotrofnih bakterija, kao i mikroorganizama koji sudjeluju u različitim etapama metabolizma dušika višestruko povećala. Budući da gljivice većinom sadrže enzim celulazu (Mutanjola, 1990), a da aminoautotrofi, oligonitrofili i slobodni dušični fiksatori spadaju uglavnom u bakterije (Petrović i sur., 1998), može se reći da je primjena pendimentalina na početku dovela do smanjenja brojnosti gljivica, a povećanja brojnosti bakterija u zemljištu. Međutim, 21 dan nakon provođenja tretmana, ukupan broj heterotrofnih bakterija je bio statistički značajno manji u svim tretiranim kontejnerima u odnosu na kontrolni. Pritom se pokazala pozitivna interakcija između broja bakterija i prisustva kišnih glista u zemljištu, budući da je ukupan broj bakterija u kontejnerima koji su sadržali gliste bio veći u odnosu na broj bakterija u kontejnerima bez glista, bez obzira na primijenjenu koncentraciju pesticida. Kišne gliste su pozitivno djelovale i na brojnost gljivica u zemljištu, budući da se njihov broj u kontejnerima sa glistama povećao 21 dan nakon tretmana u odnosu na kontrolni kontejner, dok je u kontejnerima bez glista brojnost gljivica bila višestruko niža u odnosu na kontrolu. Također, zabilježeno je pozitivno djelovanje kišnih glista i na brojnost aktinomiceta i celulolitičkih mikroorganizama, dok na brojnost aminoautotrofa, oligonitrofila i slobodnih dušičnih fiksatora prisustvo kišnih glista u zemljištu nije imalo značajan utjecaj. lako je primjena pendimentalina nakon 21 dan dovela do povećanja brojnosti specifičnih grupa bakterija (aminoautotrofa, oligonitrofila i slobodnih dušičnih fiksatora) u odnosu na kontrolni kontejner, ukupan broj heterotrofnih bakterija u zemljištu je značajno opao. Negativan utijecaj pendimetalina na ukupnu zemljišnu bakteriofloru, kao i na brojnost gljivica, ublažen je aktivnošću kišnih glista čime se ističe njihova moguća upotreba u procesima in situ bioremedijacije zemljišta kontaminiranog ovim pesticidom.

\section{Zaključak}

Pendimetalin u znatnoj mjeri utječe kako na bakteriofloru tako i na gljvice u zemljištu, ali je početni efekt ovog herbicida na ove dvije grupe organizama suprotan: dok se ukupan broj bakterija u početku značajno povećava, brojnost gljivica opada. Pendimetalin pozitivno djeluje na brojnost aminoautotrofa, oligonitrofila i slobodnih dušičnih fiksatora, tj. bakterija koje sudjeluju u specifičnom metabolizmu dušika, bez obzira na prisustvo kišnih glista. Međutim, duže izlaganje zemljišta pesticidu naposljetku dovodi i do opadanja brojnosti ukupnog broja bakterija što direktno negativno utiče na plodnost samog zemljišta. Aktivnost kišnih glista ublažava negativno djelovanje pendimetalina na zemljišnu bakteriofloru i pozitivno utječe na brojnost gljivica u zemljištu čime indirektno dovodi do povećanja kvalitete zemljišta i ukazuje na njihovu moguću upotrebu u procesima in situ bioremedijacije zemljišta kontaminiranog ovim pesticidom.

\section{Literatura}

Chikoye, D., Abaidoo, R., Fontem, L. A. (2014) Response of weeds and soil microorganisms to imazaquin and pendimethalin in cowpea and soybean. Crop Protection, 65, 168-172.

Domsch, K. H., Gams, W. (1983) Fungal in Agricultural Soils. Halsted Press (Wiley), New York.

Đorđević, S., Govedarica, M., Ajder, S., Stefanović, L. (1994) Uticaj nekih herbicida na biološku aktivnost i mikroorganizme u zemljištu. Savremena poljoprivreda, 42 (3), 125-133.

Edwards, C. A., Bohlen, P. J. (1996) Biology and ecology of earthworms. Chapman and Hall, London.

Govedarica, M., Jarak, M. (1996) Praktikum iz mikrobiologije. Univerzitet u Novom Sadu, Poljoprivredni fakultet, Novi Sad i Institut za ratarstvo i povrtarstvo, Novi Sad.

Govedarica, M., Milošević, N., Jarak, M., Konstantinović, I., Đurić, S. (1996) Uticaj herbicida na mikrobiološku aktivnost u zemljištu pod usevom kukuruza.

Zbornik radova V Kongresa o korovima, 581-586. 
Grossbard, E., Davies, H. A. (1976) Specific microbial responses to herbicides. Weed Research, 16, 163-169.

Imberger, K. T., Chiu, C. Y. (2002) Topographical and seasonal effects on soil fungal and bacterial activity in subtropical, perhumid, primary and regenerated montane forests. Soil Biology and Biochemistry, 34 (5), 711-720. doi: 10.1016/ S0038-0717(01)00236-X

ISO 17512-1 (2008) Soil quality - Avoidance test for determining the quality of soils and effects of chemicals on behaviour - Part 1: Test with earthworms (Eisenia fetida and Eisenia andrei).

Jacobsen, C. S., Hjelmsø, M. H. (2014) Agricultural soils, pesticides and microbial diversity. Current Opinion in Biotechnology, 27, 15-20. DOI: 10.1016/j.copbio.2013.09.003

Janjić, V. (1996) Triazinski herbicidi. Institut za istraživanja u poljoprivredi Srbija, Beograd.

Jarak, M., Govedarica, M. (2003) Mikrobiologija. Poljoprivredni fakultet, Novi Sad.

Johnsen, K., Jacobsen, C. S., Torsvik, V., Sørensen, J. (2001) Pesticide effects on bacterial diversity in agricultural soils - a review. Biology and Fertility of Soils, 33 (6), 443-453. doi: 10.1007/s003740100351

Kaur, S., Singh, S., Phutela, R. P. (2014) Effect of herbicides on soil microorganisms in direct-seeded rice. Indian Journal of Weed Science, 46 (3): 229-233. 38-47.

Kljajić, N., Arsić, S., Mijajlović, N. (2012) Zemljište kao ekološki faktor poljoprivredne proizvodnje. Tranzicija, 14 (29),

Kočárek, M., Artikov, H., Voříšek, K., Borůvka, L. (2016): Pendimethalin degradation in soil and its interaction with soil microorganisms. Soil \& Water Res. doi: 10.17221/226/2015-SWR

Krasiljnikov, N. A. (1965): Biologija otedeljnih grup aktinomicetov. Nauka, Moskva.

Milošević, N. (2008) Mikroorganizmi - bioindikatori zdravlja/kvaliteta zemljišta. A Periodical of Scientific Research on Field \& Vegetable Crops, 45 (1), 205-215.

Milošević, N., Govedarica, M., Jarak, M., \& Đorđević, S. (2001) Pesticidi i mikroorganizmi. U: Zaštita šećerne repe od bolesti, štetočina i korova (Konstantinović, B., Štrbac, P., Balaž, F.), str. 109-142. Stylos, Novi Sad.

Muntañola-Cvetković, M. (1990) Opšta mikologija. Naučna knjiga, Beograd.

Muturi, E. J., Donthu, R. K., Fields, C. J., Moise, I. K., Kim, C.-H. (2017) Effect of pesticides on microbial communities in container aquatic habitats. Scientific Reports, 7, 44565; doi: 10.1038/srep44565. doi: 10.1038/srep44565

Očinkova, M. F. (1976) Dinamika nekotorh svojstv dernovo-podzolistoj počv svjzi s primeneniem simazina i prometrina. Agrohimija, 11, 108-113.

Očinkova, M. F., Orlov, D. S. (1980) Izmenenie biologičeskoj aktivnosti i nekotorh drugih svojstv počv v svjazi primeneniem triazinovh gerbicidov. Agrohimija, 1, 109-118.

Petrović, O., Gajin, S., Matavulj, M., Radnović, D., Svirčev, Z. (1998) Mikrobiološka ispitivanje kvaliteta površinskih voda. Univerzitet u Novom Sadu, Prirodno-matematički fakultet, Novi Sad.

Pose-Juan, E., Igual, J. M., Sánchez-Martín, M. J., Rodríguez-Cruz, M. S. (2017) Influence of herbicide triasulfuron on soil microbial community in an unamended soil and a soil amended with organic residues. Frontiers in Microbiology, 8: 378. doi: 10.3389/fmicb.2017.00378

Radivojević, Lj., Stanković-Kalezić, R. (2000) Uticaj trifluralina i pendimetalina na mikroorganizme u zemljištu. Acta herbologica, 9, 77-84.

Radivojević, Lj. (1998) Uticaj alahlora, metalhlora i metribuzina na zemljišnom mikrofloru. (Magistarska teza). Univerzitet u Beogradu, Poljoprivredni fakultet, Beograd

Radivojević, Lj., Šantrić, Lj., Stanković-Kalezić, R., Brkić, D., Janjić, V. (2003) Uticaj metribuzina na brojnost i aktivnost nekih grupa zemljišnih mikroorganizama. Pesticidi, 18 (2), 99-107. doi:10.2298/PIF0302099R

Sarić, Z. (1992) Metode u mikrobiologiji. Nauka, Beograd.

Savage, K. E., Jordon, T. E. (1980) Persistence of three dinitroanaline herbicides on the soil surface. Weed Science, 28 (1), 105-110.

Schleicher, L. C., Shea, P. J., Stouggaard, R. N., Tupy, D. R. (1995) Efficacy and dissipation of dithiopyr and pendimethalin in perennial ryegrass (Lolium perenne) turf. Weed Science. 43 (1), 140-148.

Sebiomo, A., Ogundero, V. W., Bankole, S. A. (2011) Effect of four herbicides on microbial population, soil organic matter and dehydrogenase activity. African Journal of Biotechnology, 10 (5), 770-778.

Tamburić, Lj., Lević, J. (1995) Uticaj atrazina, EPTC-a i njihove smeše na brojnost mikroorganizama u zemljištu pod usevom kukuruza. Pesticidi, 10 (3), 219-230.

Tomlin, C. (Ed.) (2000) The Pesticide Manual (12th Ed.). British Crop Protection Council, UK.

WSDA (2004) Pendimethalin Use Summary. Unpublished report developed by the Washington State Department of Agriculture. 19 p.

Zimdahl, R. L., Catizone, P., Butcher, A. C. (1984) Degradation of pendimethalin in soil. Weed Science, 32 (3), $408-412$. Zulalian, J. (1990) Study of the absorption, excretion, metabolism, and residues in tissues of rats treated with carbon-14-labeled pendimethalin, PROWL herbicide. Journal of Agricultural and Food Chemistry, 38 (8), 1743-1754. doi: $10.1021 /$ jf00098a025

Prispjelo: 17.8.2018

Prihvaćeno: 20.9.2018. 